\title{
Cutaneous Pseudolymphoma Due to Hirudotherapy
}

\section{Hirudoterapiye Bağll Kutanöz Psödolenfoma}

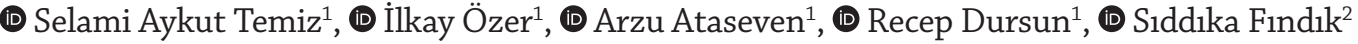 \\ ${ }^{1}$ Necmettin Erbakan Univercity Meram Faculty of Medicine, Department of Dermatology, Konya, Türkiye \\ ${ }^{2}$ Necmettin Erbakan Univercity Meram Faculty of Medicine, Department of Pathology, Konya, Türkiye
}

Cite this article as: Temiz SA, Özer İ, Ataseven A, Dursun R, Findık S. Cutaneous Pseudolymphoma Due to Hirudotherapy

Turkiye Parazitol Derg 2019;43(1):50-2.

\begin{abstract}
Pseudolymphoma, also known as Jessner's lymphocytic infiltration, is a benign but usually chronic, T-cell infiltrating disease with erythematous papules and plaques usually seen on the skin of the face, neck, and back. The use of leech therapy also known as hirudotherapy has increased in recent years. Here, we report a 52-year-old male patient who had undergone hirudotherapy in his neck and developed infiltrating plaques after four months. A skin biopsy confirmed the diagnosis of Jessner's lymphocytic infiltration. In parallel with the increasing use of hirudotherapy in recent years, the side-effect reports will likely to increase. Indications and contraindications of hirudotherapy, which is being used officially in hospitals, should be taken into consideration. Keywords: Pseudolymphoma, hirudotherapy, leech, side effects
\end{abstract}

Öz

Psödolenfoma diğer adıyla Jessner'in lenfositik infiltrasyonu; genellikle yüz, boyun ve sırtta görülebilen, eritematöz papül ve plaklarla seyreden, derinin benign; ancak genellikle kronik, enfiltratif bir T-hücre hastalığıdır. Hirudoterapi olarak da bilinen sülüklerle tedavinin kullanımı son yıllarda giderek artmaya başlamıştır. Bu yazıda, dört ay önce boynuna hirudoterapi yaptırmış ve sonrasında enfiltratif plaklar gelişmiş 52 yaşında bir erkek olgu bildiriyoruz. Deri biyopsisi ile Jessner' in lenfositik infiltrasyonu tanısı doğrulanmıştır. Son yıllarda giderek artan kullanıma paralel olarak hirudoterapinin yan etki bildirimlerinin artacağı muhtemeldir. Hastanelerde de resmi olarak kullanılmaya başlanan hirudoterapinin endikasyonları ve kontrendikasyonları göz önünde tutulmalıdır.

Anahtar Kelimeler: Psödolenfoma, hirudoterapi, sülük, yan etkiler

\section{INTRODUCTION}

Jessner's lymphocytic skin infiltration is a benign disease in which cutaneous T-lymphocyte infiltration with unknown etiology occurs (1). The lesions usually reside in the head, neck, and body. The disease may show chronic or persistent resistance for months or years (2). The diagnosis of the disease, which can be confused with many other clinical conditions such as cutaneous lymphomas, discoid lupus erythematosus, polymorphic light eruptions, drug eruptions and angiolenfoid hyperplasia, is made by histopathologically demonstrating lymphocytic infiltration in a skin biopsy (1).

Most of the leeches are ectoparasites and are living organisms that feed by blood sucking (3). Leeches have been used in the treatment of certain diseases since ancient times, (3) and are mainly used for phlebotomy. The U.S. Food and Drug Administration allowed the use of leeches in the USA in plastic surgery and microsurgery starting in 2004 (4). Pain, itching, hypotension, vasovagal attacks, anemia, infections, allergic reactions, and keloid formation have previously been reported as side effects in leech therapy (5).

We presented here a case of Jessner's lymphocytic infiltration after leech therapy which was not previously reported in the literature.

\section{CASE REPORT}

A 54-year-old male patient was admitted to our polyclinic complaining of an itchy red skin lesion in his neck over the last two weeks. He reported that leech therapy was applied to the areas corresponding to the zone of redness in his neck four months ago.

\section{Received/Geliş Tarihi: 23.05.2018 Accepted/Kabul Tarihi: 27.12.2018}

Address for Correspondence/Yazar Adresi: Selami Aykut Temiz MD, Necmettin Erbakan Univercity Meram Faculty of Medicine, 


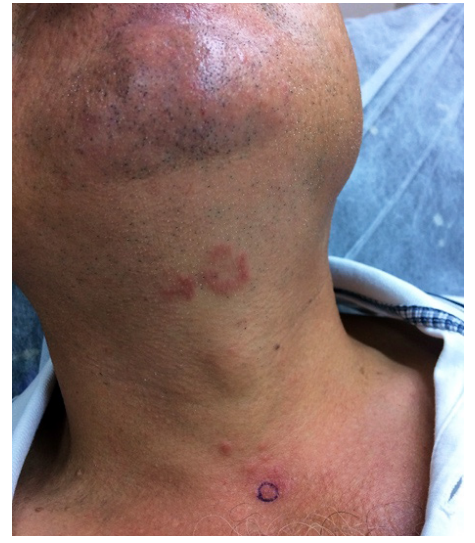

Figure 1. The dermatological examination, there were two to three erythematous, central normal-looking, infiltrated plaques in his neck.

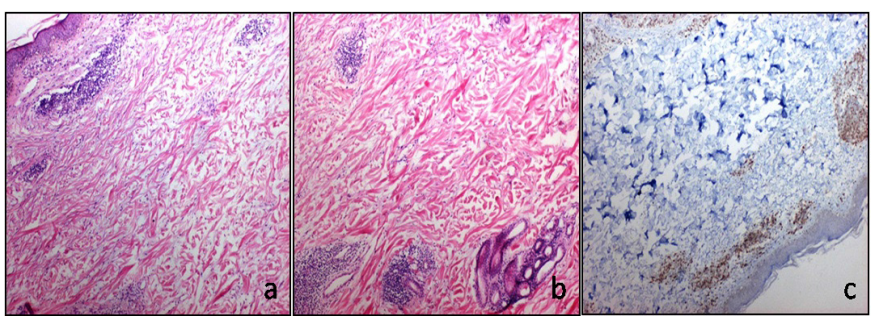

Figure 2 a. x40 H\&E- perivascular lymphocyte infiltration in the dermiş b. $x 40 \mathrm{H} \& \mathrm{E}$ - perivascular lymphocyte infiltration in the dermiş c. $x 40$ Immunohistochemical CD-3 positive lymphocytes

The medical history of the patient had no additional features other than leech therapy. On dermatological examination, there were two to three erythematous, central normal-looking, infiltrated plaques in his neck (Figure 1). In terms of fungi, the native examination was negative.

In terms of a differential diagnosis, a skin biopsy was performed with polymorphic light eruption, cutaneous sarcoidosis, cutaneous lupus erythematosus, discoid lupus erythematosus, lupus tumidus, and lymphocytoma cutis preliminary diagnoses. A histopathological examination revealed mild hyperkeratosis of the epidermis and perivascular CD3 + intense patch-like lymphocytic infiltration of cells in the papillary and reticular dermis (Figure 2). The findings were consistent with Jessner's lymphocytic infiltration. Because no other trigger could be detected, it was thought that the cutaneous pseudolymphoma was due to leech therapy.

The patient was treated with intralesional corticosteroid, and at an inspection one month after treatment inspection, the lesions were regressed, and no recurrence was observed after six months of follow-up. Informed consent was obtained from the patient for the publication of this case report and images.

\section{DISCUSSION}

Cutaneous pseudolymphoma allude to a heterogenous group of benign hyperplastic lymphoid infiltrates of the skin (1). The etiopathogenesis of the disease is unclear; it is thought that cutaneous pseudolymphomas may be associated with drugs (antidepressant, phenothiazine, benzodiazepine, lithium, anticonvulsants), trauma (arthropod bites, tattoos, vaccines, foreign matter injections), microbial agents (Borrelia burgdorferi, Helicobacter pylori) (1). The microscopic outlook can imitate cutaneous lymphomas clinically and/or histologically, but the clinical process is benign (6). Progression to cutaneous lymphoma has been observed but is an uncommon phenomenon (6). In addition to cutaneous lymphomas, a diagnosis can also be confused with polymorphic light eruption, cutaneous sarcoidosis, cutaneous lupus erythematosus, discoid lupus erythematosus, and lupus tumidus (7). Differential diagnosis is very important in terms of mixing with other important diseases. Cutaneous pseudolymphoma is very difficult to clinically differentiate with other differential diagnoses. Although the diagnosis of cutaneous pseudolymphoma can be made by histopathological examination, it is sometimes difficult to distinguish between malignant or benign cutaneous lymphocytic infiltration. Histopathologically, the lymphoid hyperplasia of the skin shows a very exaggerated dense nodular infiltrate that primarily covers the dermis and shows a decrease in the deep dermis and subcutaneous adipose tissue. The infiltrate is usually separated from the epidermis by a pronounced "grenz zone" osit and consists largely of mature, small large lymphocytes, histiocytes, plasma cells, dendritic cells and eosinophils $(6,7,8)$. The histopathology of our case was compatible with lymphoid hyperplasia in these aspects.

Cutaneous pseudolymphoma is a chronic resistant skin pathology with relapses. Even though the disease itself is benign, many studies may be needed in terms of a differential diagnosis due to the importance of such a diagnosis. The lesions are usually asymptomatic, and symptoms such as burning and pruritus can also be observed (8). In our case, itching was present.

Topical, intralesional, and systemic corticosteroids; antimalarials; tetracycline; cryotherapy; radiotherapy; laser therapy; and dapsone may be prescribed for the treatment of cutaneous pseudolymphoma (9). However, the success of the treatment is limited, and recurrence is frequent. In our case, our treatment with intralesional corticosteroid treatment was successful.

The most common complication after leech therapy is the prolongation of bleeding time. Allergic reactions to leech saliva and some bacterial infections may also occur (10). Allergic reactions that start as simple itching can also be seen in the form of a burning sensation, and, even worse, can cause ulcerative necrosis. These complications are thought to be due to toxins found in leech saliva (11). Depending on the number of leech bites, severe anemia can result which can lead to serious bleeding and even death (12).

Due to the reuse of leeches, infection and scar tissue can develop on the treated area (6). Aeromonas spp., found in leech saliva, is the most common cause of leech infections (13). The use of prophylactic antibiotics may reduce this risk factor.

The cause of this cutaneous pseudolymphoma was suspected to be trauma caused by a leech bite. To the best of our knowledge, the development of cutaneous pseudolymphoma due to leech therapy has never been reported before.

\section{CONCLUSION}

Along with the increasing use of hirudotherapy, reports of sideeffects are likely to increase and physicians should be aware. 
* Ethics

Informed Consent: Informed consent was obtained from the patient for the publication of this case report and images.

Peer-review: Internally peer-reviewed

\section{* Authorship Contributions}

Concept: S.A.T., İ.Ö., R.D., A.A., S.F., Design: S.A.T., İ.Ö., R.D., Data Collection or Processing: S.A.T., İ.Ö., S.F., R.D., Analysis or Interpretation: S.A.T., İ.Ö., A.A., S.F., Literature Search: İ.Ö., S.A.T., R.D., Writing: S.A.T., İ.Ö., R.D.

Conflict of Interest: No conflict of interest was declared by the authors.

Financial Disclosure: The authors declared that this study received no financial support.

\section{REFERENCES}

1. Zhou LL, Mistry N. Cutaneous lymphoid hyperplasia (pseudolymphoma). CMAJ 2018;190:E398.

2. MiguelD, Peckruhn M,ElsnerP.TreatmentofCutaneousPseudolymphoma: A Systematic Review. Acta Derm Venereol 2018;98:310-317.

3. Gödekmerdan A, Arusan S, Bayar B, Saglam N. Medicinal leeches and hirudotherapy. Türkiye Parazitolojii Dergisi 2011;35:234.
4. U.S. Food and Drug Administration Dept of Health and Human Services. http://www.fda.gov/fdac/features/2004/504_leech.html

5. Okka B. Hirudotherapy from past to present. Eur J Basic Med Sci 2013;3:61-5.

6. Rai VM, Balachandran C. Multiple infiltrated nodules and plaques. Lymphocytic infiltrate of Jessner. Dermatol Online J 2006;12:26.

7. Lipsker D, Mitschler A, Grosshans E, Cribier B. Could Jessner's lymphocytic infiltrate of the skin be a dermal variant of lupus erythematosus? An analysis of 210 cases. Dermatology 2006;213:15-22.

8. Ziemer M, Eisendle K, Müller H, Zelger B. Lymphocytic infiltration of the skin (Jessner-Kanof) but not reticular erythematous mucinosis occasionally represents clinical manifestations of Borrelia-associated pseudolymphoma. Br J Dermatol 2009;161:583-90.

9. Michel JL, Perrin D. Pulsed dye laser treatment for Jessner's lymphocytic infiltration of the skin. Ann Dermatol Venereol 2010;137:803-7.

10. Karadag AS, Calka O, Akdeniz N, Cecen I. A case of irritant contact dermatitis with leech. Cutan Ocul Toxicol 2011;30:234-5.

11. Itrat M, Zarnigar, Haque N. Historical aspects of leech therapy: a critical review. Int J Health Sci Res 2013;3:78-83.

12. Kose A, Zengin S, Kose B, Gunay N, Yildirim C, Kilinc H, et al. Leech bites: massive bleeding, coagulation profile disorders, and severe anemia. Am J Emerg Med 2008;26:1067.e3-1067.e6.

13. Ardehali B, Hand K, Nduka C, Holmes A, Wood S. Delayed leech-borne infection with Aeromonas hydrophilia in escharotic flap wound. J Plast Reconstr Aesthet Surg 2006;59:94-5. 